\section{Russell's American Lecture Courses}

In the above article Harry Ruja has covered Russe11's single lectures in the United States and Canada, including those given at universities and colleges. However, during socene Russell gave full courses at the universities. So far very little is had agrod in 1912 to give the 1914 Lowe1l Letures, and also to offer had agreed, th 1912, to give the 14 Lowed Lectures, and also to offer courses on The Ralph Barton Perry, who was in charge of arrangements for Russe11, asked him for "brief descriptions" of the courses for the Department's course hulletin. following appeared in the 20 May 1913 issue of the afficial Register of Harvard University:

Theory of Knowledge

Criticism of current theories: idealism, the pragmatist theory of truth, Bergson's "intuition" and "intellect". Logical apparatus: simples and complexes, relations, particulars and universals, truth and falsehood. Psychological apparatus: acquaintance, belief, analysis, self-evidence. The data of knowledge: varieties of realism. Our knowledge of space, time, and matter. Induction. Causality.

Advanced Logic

Outline of recent developments: Peano; Frege, Cantor and the
Influence of mathematics. Definition of logic: generalization and logical form. Logic not concerned with thought or with any

special subject-matter. Classification of complexes; particulars, predicates, and relations of various orders. Premises and inference; distinction between premises and hypotheses. The meaning of "existence"; descriptions, classes. Identity of logic and mathematics. Relation of logic to the natural sclences, to metaphysics, and to theory of knowledge. Unsolved problems of logic.

There was some doubt, among Russell's bibliographers, that these descriptions were the ones Russell sent. Happily his authorship has now been confirmed. The other day in the Archives I was able to match up the printed descriptions with two pages of Ms which had always been associated with the unpublished Theory of Knowledge Ms, but which I had considered merely notes for that work. There are slight changes from the M.s version, but none of substance. It is expected that the Theory of Knowledge description will prove usèful when it is compared with Victor F. Lenzen's notes on the lectures themselves. Changes in the topics discussed may very well show up, since it was between April 1913 and Spring 1914 that Russell was hit by the "first wave" of Wittgenstein's impact (My Philosophical Development, Ch. X). In this connection, it is a pity no copy of the "detailed syliabus" of the Theory of Knowledge lectures, which Russe11 sent Perry on 9 November 1913 and which Perry acknowledged, has come to light.

For an account of the course on Advanced Logic, readers are referred to Harry T. Costello's "Logic in 1914 and Now", in the dournal of Philosophy, 54: 25 Apri1 1957, 243-64. Coste1lo was Russell's assistant in Logic at Harvard.

Almost nothing is known of the other courses Russell gave at American universities. Perhaps students of Russell at the universities which appear on the following list would check their university calenders for those years. There may be other brief course descriptions which can be ascribed to Russell. I don't, however, expect any more syllabi to turn up. Russell usually prepared them for non-institutional courses, such as those on "Principles of Social Reconstruction" (1916), and Mathematical Logic and "The Philosophy of Logical Atomism" (1917-18). Incidentally, although John Slater has managed to acquire a copy of the first, no copies are known of the other two syllabi. Also very useful would be student newspaper reports of Russells lectures. The Archives recently obtained copies of such reports of Russell's five lectures on "Postulates of the bctober - 3 November 1943 .

What I know about Russell's other courses follows:

\begin{tabular}{|c|c|}
\hline $\begin{array}{l}1896, \\
\text { fal1 }\end{array}$ & $\begin{array}{l}\text { Bryn Mawr } \\
\text { Johns Hopkins }\end{array}$ \\
\hline 1938-9 & $\begin{array}{l}\text { University of } \\
\text { Chicago }\end{array}$ \\
\hline $1939-40$ & UCLA \\
\hline $\begin{array}{l}1940, \\
\text { fal1 }\end{array}$ & Harvard \\
\hline $1941-2$ & Barnes Foundation \\
\hline 1944 & $\begin{array}{l}\text { Rand School, } \\
\text { New York }\end{array}$ \\
\hline
\end{tabular}
non-Euclidean geometry

general course on ? "Words and Facts" introductory philosophy seminar on "Words and Facts" seminar (in addition to the Wilitam James Lectures)

history of philosophy

"Philosophies in Practice". [A copy of the brief syllabus for this course has been obtained from Paul Schilpp.]

Russell's lecture courses in Britain, and in other parts of the world, are another matter entirely and must be left to another article.

Bertrand Russell Archives

Kenneth B1ackwe11 